\title{
How human capital, universities of excellence, third party funding, mobility and gender explain productivity in German political science
}

\author{
Isabel M. Habicht ${ }^{1,2} \cdot$ Mark Lutter $^{2} \cdot$ Martin Schröder $^{1}$ (D)
}

Received: 2 June 2020 / Accepted: 17 January 2021 / Published online: 29 October 2021

(c) The Author(s) 2021, corrected publication 2022

\begin{abstract}
Using a unique panel dataset of virtually all German academic political scientists, we show that researchers become much more productive due to the accumulation of human capital and third party funding. We also show however, that while universities of excellence have more productive researchers, individuals who go there do not become more productive. Finally, we show how women publish only 9 percent less than men with the same level of prior publication experience, but are about 26 percent less productive over their entire career, as early productivity leads to later productivity, so that women increasingly fall behind. These results cannot be explained through the influence of childbearing. Rather, they support the 'theory of limited differences', which argues that small differences in early productivity accumulate to large differences over entire careers, as early success encourages later success. Apart from generally showing why political scientists publish more or less, we specifically identify accumulative advantage as the principal reason why women increasingly fall behind men over the course of their careers.
\end{abstract}

Keywords Accumulative advantage $\cdot$ Political science $\cdot$ Matthew effect $\cdot$ Research productivity $\cdot$ Third party funding $\cdot$ Excellence initiative $\cdot$ Publications · Gender gap · Female productivity puzzle

\section{Introduction}

Why are some scientists more productive? Productivity in science is commonly measured through publications, especially peer-reviewed ones (Gerhards, 2002: p. 19f.; Hix, 2004: p. 296ff.; Jungbauer-Gans \& Gross, 2013: p. 84; Long et al., 1993: p. 703; Münch, 2006: p. 473; also cf. Merton, 1973 [1942]: p. 270). But are some researchers innately more productive? Or do successful researchers start with average productivity and then become more and more successful, as small differences in early productivity accumulate to large

Martin Schröder

martin.schroeder@uni-marburg.de

Institute of Sociology, University of Marburg, Ketzerbach 11, 35032 Marburg, Germany

2 Institute of Sociology, University of Wuppertal, Gaußstr. 20, 42119 Wuppertal, Germany 
differences over time (Jonathan R. Cole \& Singer, 1991: p. 286f; Merton, 1968: p. 7)? By using a unique data set of virtually all German academic political scientists, we disentangle the two processes and show what high productivity depends on. Prior studies indicate that productivity may depend on one's prior publication experience as well as third party funding; they also suggest that women are only slightly less productive at first, but then increasingly fall behind as they accumulate less experience that would lead to further success. Existing studies also show how universities of excellence have more productive researchers, but do not increase the productivity of researchers who went there (Lutter \& Schröder, 2016, 2020; Schröder et al. 2021). We confirm these results in political science. The following sections show to which theoretical discussions this contributes and why existing studies were not able to deliver the answers that we provide.

\section{Theory}

\section{Human capital}

Researchers may be more productive because they are endowed with more human capital, which consists of individual resources, knowledge and skills acquired through education and on-the-job training (Becker, 1993 [1964]: p. 11). Researchers should therefore be more productive if they have more advanced educational degrees from better institutions. However, the human capital approach has been considered too simplistic (cf. the summary in Marginson, 2019). In academia, one complication is that a form of "on the job training" exists in the form of publishing: the more one has already published, the more practice one has in publishing, which in turn makes it easier to publish even more in the future. In this sense, Bourdieu (2004: p. 61f.) argued that accumulated scientific successes "are the materialization both of the gains won in earlier phases of the game and weapons capable of being used in the subsequent rounds."

Publications are thus not only an output of past human capital, but also an input to further human capital (cf. Becker, 1993 [1964]: p. 98; Bourdieu, 2004: p. 55). We call this human capital, rather than scientific capital, as it is strongly linked to a specific person. The self-reinforcing mechanism that is postulated behind this is known as the "Matthew Effect," where early success leads to later success (Merton, 1968: p. 58). An alternative name for this accumulation of success is the "accumulative advantage" hypothesis, which argues that small initial differences lead to large productivity differences over time (Allison \& Stewart, 1974: p. 597f.; Merton, 1968: p. 7). Allison and Stewart (1974: p. 596) argue for an alternative possibility, namely that "there are substantial, predetermined differences among scientists in their ability and motivation to do creative scientific research." If this is correct, then some researchers should be more productive even at the beginning of their career and regardless of their prior experience. They would be "naturally" endowed with more human capital, irrespective of what they have accumulated over time. However, if the opposite "accumulative advantage" hypothesis is correct, then productivity mainly results from prior experience, so that it differs little between researchers with the same prior experience.

To test which is the case, we show which types of experience make researchers more or less productive and whether productivity differences mainly exist because of different levels of research experience, which would fit an accumulative advantage process, or whether differences in productivity exist even at the same level of prior experience. But what counts as productivity-increasing experience in the first place? Existing studies not only find that 
prior publications are a strong predictor of future publications (Lee, 2019: p. 1500; Lindahl et al., 2020: p. 326). They also argue that the duration and quality of one's education, third party funding and gender impact productivity.

\section{Duration, quality and social capital of one's education}

As mentioned, productivity may depend on the accumulation, rather than mere initial presence of human capital. One way to measure the accumulation of human capital, apart from prior publications, are career steps. Academics may publish more with each successive career step, such as getting a $\mathrm{PhD}$ and finally a tenured professorship. In other words, the more advanced a researcher is, the more human capital she or he may have accumulated, which allows for more publications. However, it is unclear whether productivity simply increases with career steps or first increases and then decreases, for example because researchers publish a lot while trying to get a tenured professorship, while falling behind their prior publication trajectory as soon as they have tenure (S. Cole, 1979: p. 976f.).

It is not only unclear whether the quantity, but also whether the alleged quality of one's prior education increases productivity. Some German universities have recently been named "universities of excellence" by the so-called "German Universities Excellence Initiative." These universities are supposed to provide "outstanding conditions for cuttingedge research" and exceptional "assistance to support its young scholars in their research" (DFG, 2013: pp. 12, 34). However, whether so-called universities of excellence indeed help researchers to be more productive is unclear, as "[b]ibliometric analyses with the aim of measuring the direct effects of the German Excellence Initiative have not been carried out so far" (Möller et al., 2016: p. 2219).

Effects from other countries also give no clear guidance. While some suggest that the prestige of one's department hardly explains a scholar's productivity sufficiently (GarcíaSuaza et al., 2020: p. 446), others ask about the causality behind such "determinants of productivity: Is it due to intrinsic abilities or to a departmental effect?" (Carayol \& Matt, 2006: p. 60). Cross-sectional data cannot disentangle whether researchers at some universities publish more due to their intrinsic ability, or due to an actual departmental effect, where a researcher becomes more productive after having been at a reputable department, irrespective of her or his prior productivity (Long, 1978: p. 889).

Apart from the quantity and quality of one's education, international experience may also increase productivity. Authors such as Kathrin Zippel (2017) argue that women can make up for being discriminated against at their home institution by getting recognition abroad. But while some find that mobility indeed increases productivity (Dubois et al., 2014: p. 1687), others find little such effect (Fernández-Zubieta et al., 2015: p. 109f.). Also, just as with other influences, mobility may be both an input to productivity, as well as an output of productivity, such as when more productive researchers are more likely to be invited to prestigious institutions (Dubois et al., 2014: p. 1671). It is therefore again important to disentangle both effects. This can be done first by measuring the relationship between productivity and international experience. And then, second, by measuring how much of this relationship persists after accounting for prior productivity, with the latter showing whether international experience makes researchers more productive irrespectively of what they have published so far.

Not only can international mobility be an asset, but mobility generally can also be helpful, by bringing social capital that can be defined as "the aggregate of the actual or potential resources which are linked to possession of a durable network of more or less 
institutionalized relationships" (Bourdieu, 1986: p. 21). Similar to other factors that lead to success, social capital comes from one's prior career, but can also lead to future productivity. To illustrate this, imagine a researcher who on the one side knows others because of past research, but then uses these contacts as co-authors to increase his or her future productivity. However, whether this is the case is unclear. While existing studies argue that social capital may increase productivity in sociology (Lutter \& Schröder, 2020: p 455) and computer science (Jadidi et al., 2018: p. 1750011-2f.), it is yet unknown whether this is also the case in other disciplines, such as political science.

\section{Third party funding}

Researchers may not only be more productive if they have been more productive in the past and if their education was longer, more prestigious and more international, but also if more money is invested in them. However, whether third party funding indeed increases publications is unclear (Jansen et al., 2007: p. 130). While some find weak effects (Carayol \& Matt, 2006: p. 70), others suggest that for a doubling of third party funding, German business departments become 24 percent more productive (Albers, 2015: p. 25). However, even studies that do find effects argue that replications in "different scientific disciplines" are needed, urging to use "panel data that allow for the detection of causal effects" (Albers, 2015: p. 30). The main problem is again one of endogeneity (Bolli \& Somogyi, 2011: p. 138; also cf. Jansen et al., 2007: p. 137), as cross-sectional studies leave unclear whether researchers who are more productive in the first place acquire more funding or whether funding itself increases publications irrespective of prior productivity (Bolli \& Somogyi, 2011: p. 146; Hornbostel, 2001: p. 536; Jansen et al., 2007: p. 130). Some even fear that funding by the German Research Foundation (Deutsche Forschungsgemeinschaft or DFG), is distributed through scientific cartels, monopolies and oligarchies (Münch, 2006: p. 466), while others claim that this is not the case (Auspurg et al., 2008: p. 680). Even though such studies disagree on much, they usually agree that productivity can be measured by relating it to publications (Münch, 2006: p. 472). One therefore has to show how funding affects the productivity of researchers above and beyond their pre-funding productivity.

\section{Gender}

Across scientific disciplines, career stages and birth cohorts, women publish less than men (Jaksztat, 2017: p. 357; Jonathan R Cole \& Zuckerman, 1987: p. 199; Leahey, 2006: p. 756; Sax et al., 2002: p. 424). The theory of limited differences spells out how cumulative advantage and the Matthew effect may lead to this, arguing that small initial differences accumulate over time to produce large differences over entire careers. For example, if only a small share of professors is unwilling to sponsor female students, this may make little difference at the beginning of careers, as women can switch to other professors. But it stops women from getting a head start and because small differences in early success accumulate to big differences later on, limited differences early on can make women publish much less over entire careers (Jonathan R. Cole \& Singer, 1991: p. 282ff.; Long, 1990: p. 1310f.; Xie \& Shauman, 1998: p. 857ff.).

But can the female productivity gap really be explained as the result of less accumulated experience? Some suggest that 60 percent of the gap can be, while arguing that about 40 percent of the female success gap remains, even at similar levels of experience (Johnson \& Stafford, 1974: p. 902). However, such analyses have been found wanting, largely because 
they do not use longitudinal data that disentangles productivity differences at the same career stage, versus productivity differences over entire careers (Strober \& Quester, 1977). It is therefore necessary to use panel data that first shows overall productivity differences, to then compare these to differences at the same career stage, when prior productivity is held constant.

But why should women accumulate productivity slower than men do in the first place? The most prominent explanation is because they rear children (Mason et al., 2013: p.29; Rivera, 2017: p. 1114). However, while some studies do find that children make women less productive, others do not (Jonathan R Cole \& Zuckerman, 1987: p. 125; Sax et al., 2002: p. 435; also compare for the literature review in Hunter \& Leahey, 2010). We therefore propose to compare, first, how much women publish less overall and, second, how much less they publish with the same level of experience. Controlling this for the effect of children not only shows whether the lower publications of women can be explained through a process of cumulative falling behind, but also whether children explain this cumulative falling behind. In the following, we show which data allows us to distinguish these effects.

\section{Data and methods}

\section{Dataset}

During the year 2019, we hand-coded all CV and publication data of all 1455 political scientists with at least one publication. We used each department and faculty website of each German university and of the two main social science institutes for basic research in Germany, notably the Max Planck Institute for the Study of Societies and the WZB Berlin Social Science Center. Every researcher's data ends when the coding of our data occurred or with the last publication we could find. For example, when a researcher's last publication was in 2017, our coding of this researcher ends in 2017. This is similar to a panel where some respondents missed the last round of interviews. Our coding strategy provides a unique panel dataset of 18,308 person-years with individual career and publication data of virtually every academic political scientist in Germany. Because we lag all independent variables by one year to avoid simultaneity bias in the regressions, we only use 16,853 person-year observations, from which 5505 are from women and 11,348 from men. Having a virtually complete sample means that statistically insignificant effects do not result from a low sample size but from actual variation in what explains productivity. Many codings were performed twice to check inter-coder reliability. We also performed extensive consistency checks on the data. For example, we checked in our dataset how much researchers publish annually or how much time passed between their career steps and then re-checked this through their website. We added information on third party funding from the so-called Gepris website of the German Research Foundation (DFG). We then surveyed every researcher about whether they have children and when these were born. The response rate was 64 percent. All information was then anonymized, so that it becomes impossible to retrace which data points belong to which researcher.

Why did we look at political science? The Matthew effect, where early productivity breeds later productivity, is said to be more important in "big science, with its expensive and often centralized equipment needed for research" (Merton, 1968: p.57). That early productivity leads to laboratory equipment, which leads to later productivity, should not be the case in political science. So we focus on this discipline, because if we find evidence of a 
Matthew effect there, it likely also exists elsewhere. Another advantage is that-compared to other fields-political science's gender distribution is not very skewed (905 men and 550 women), so that selectivity should be less of a problem than in other fields. If we look at engineering, for example, there would likely be few female scientists, which means that those who do exist are strongly selected. Contrary to this, political science, with its relatively equal gender representation, should be freer from gender-biased selection than other fields, making it an important case study.

\section{Variables}

Our dependent variable is each year's publications in SSCI (Social Sciences Citation Index $)^{1}$ journals, as defined by the Web of Science database. We therefore only use articles from journals with a certified peer review process, even though we replicate our analysis with monographs and non-SSCI articles. We have weighed for co-authorship with the formula $2 /($ number of authors +1$)$. This counts single-authored publications as 1 publication, publications with one co-author as 0.67 , with two co-authors as 0.5 , and so on. We will however replicate our analysis by counterfactually considering every article to be singleauthored. We explain each year's current, rather than accumulated publications, as annual articles have to be "re-earned" every year, thereby measuring present, rather than past productivity (Xie \& Shauman, 1998: p. 849). We control the influence of past on current productivity by controlling for six different types of accumulated past publications: prior SSCI articles, non-SSCI articles, monographs, edited volumes, gray literature and book chapters. This allows measuring how much a researcher publishes every year, irrespective of her or his productivity so far.

Our first model shows whether women publish less than men and less than men with similar prior experience. This shows whether productivity can be explained through gender per se or through less experience in publishing.

Second, to understand what other influences may lead to cumulative advantage, we add career stages, distinguishing having no $\mathrm{PhD}$ from being a postdoc and a tenured professor. ${ }^{2}$ We measure international experience through months abroad and having a $\mathrm{PhD}$ from abroad. We measure opportunities to accumulate social capital by how often a researcher changed to a new institution, the accumulated number of past co-authors and by how often a researcher acted as an interim professor. We measure the alleged quality of one's education by the share of career steps passed at so-called universities of excellence. In doing so, we code every university as a university of excellence that held this title at least once. We then coded every researcher who graduated from such a university as having graduated from a university of excellence, regardless of whether the university had the title at that specific point in time. The reasoning behind this is that the prestige of a university should precede the title university of excellence, since otherwise, the university could not have gotten the title in the first place.

\footnotetext{
${ }^{1}$ Strictly speaking, some of the publications (6\%) are listed in the SCIE index. However, to simplify, we speak of both SSCI and SCIE publications as SSCI publications, as this is the vast majority of publications we describe.

${ }^{2}$ In early calculations, we split the group of those with a $\mathrm{PhD}$ degree into those who are writing a "habilitation" (a second dissertation, specific to the German system) and who are assistant professors. But results were the same for all categories, so we merged them into one category.
} 
A third model adds the variable DFG funding, which measures how many projects a researcher had funded by the German Research Foundation. While we would have liked to include how much funding each project received, this is not possible with the Gepris databank, which only lists funded projects, but not the funding amount.

Fourth, we account for the presence of children in the household. Existing studies argue that "[s]imply having kids [rather than their number or age] appears to be the deciding factor" (Mason et al., 2013: p. 29). However, to make sure that our results are not biased by the age of children, we account for this in separate regressions.

Fifths and sixths, we use separate models for men and women to test whether their productivity is influenced differently by the variables.

We log all publications, as well as months abroad, DFG funding, co-authors, mobility and interim professorships to account for diminishing returns, as e.g. having been funded by the DFG six versus five times should make less of a difference than having been funded once versus not at all (Jansen et al., 2007: p. 137f.). 13 percent of researchers have only published "selected publications." We code them with a dummy variable "incomplete," which accounts for their missing publications.

\section{Methods}

We first show descriptively who publishes how much. We then use random effects (RE) regressions that are still rather descriptive, as they simply show who publishes how much due to what influence. To come closer to showing a causal influence, we next use RE models that control for prior productivity. This shows what gets researchers to publish more than a typical publication trajectory in political science. We then use fixed effects (FE) models that not only control for a researcher's publication trajectory so far, but also for inert talent, by showing which influences render the same researcher more productive than she or he usually is (Dubois et al., 2014: p. 1672; Joecks et al., 2014: p. 521). This makes it impossible to compare time-invariant characteristics such as gender, but it shows how much more (or less) researchers publish after different influences, such as having been at a university of excellence, receiving funding, childbirth, etc.

\section{Results: who is more productive?}

\section{Bivariate and descriptive}

First, we correlate our outcome variable bivariately with each explanatory variable and graph the results. Figure 1 therefore gives a first overview of what is related to publishing more annual SSCI publications.

Figure 1 shows how, bivariately, the strongest predictor of current SSCI articles are past accumulated SSCI articles, while, conversely, the strongest predictor of low productivity is not (yet) having a $\mathrm{PhD}$. This is first evidence of a process of cumulative advantage, as it indicates that those who have published more in the past also publish more currently, and conversely, that having little experience depresses publications more than anything else. It is also interesting to note that DFG funding is strongly related to annual publications, while a higher share of degrees from a university of excellence is not.

To test for further evidence of a process of cumulative advantage, Fig. 2 shows how current annual publications depend on prior accumulated publications. 


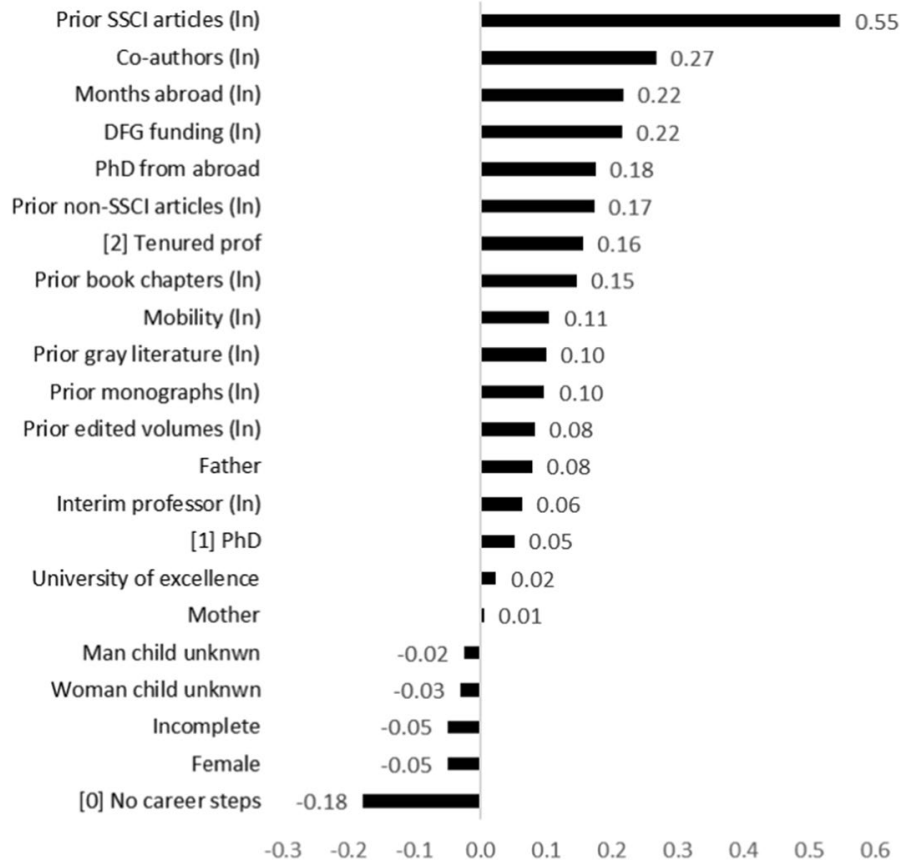

Fig. 1 Bivariate correlation to annual SSCI publications

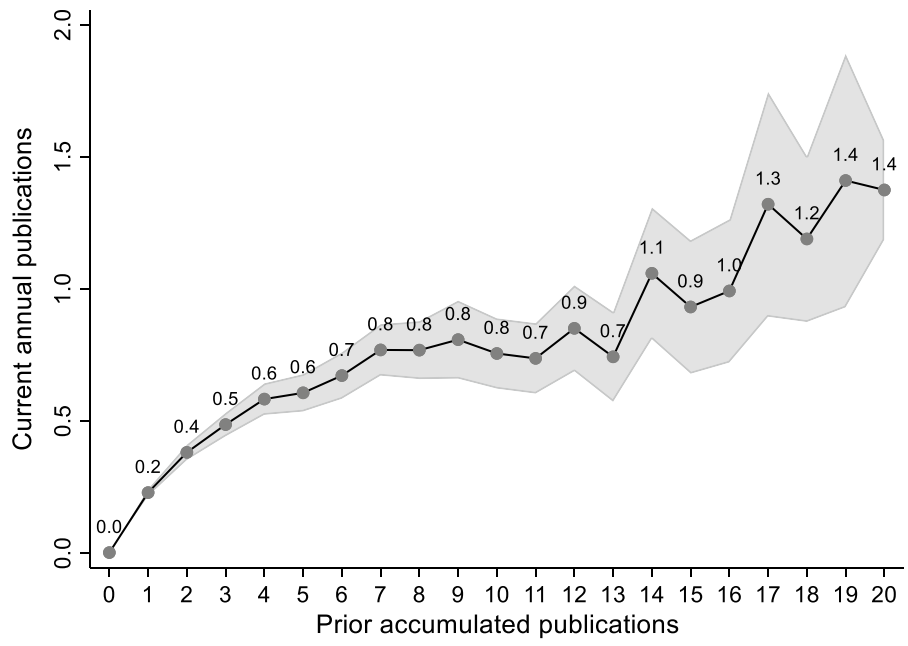

Fig. 2 How prior SSCI publications are related to current publications

Figure 2 shows that researchers publish more annually (y-axis) if they have already published more in the past (x-axis). For example, researchers who have merely published one article in the past also publish only a fifth of an article annually (or one article every five years). However, researchers who have already published 14 articles in the past publish 


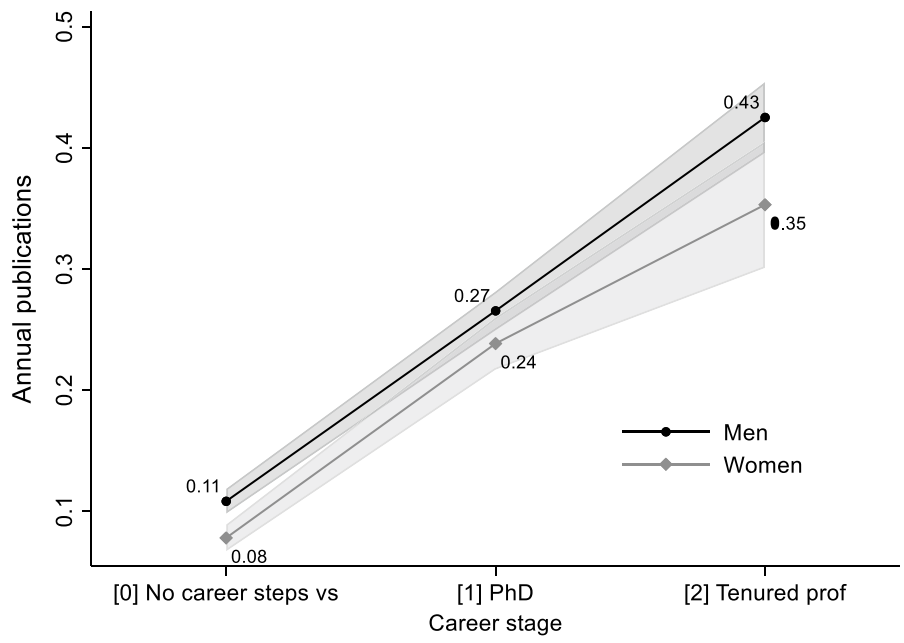

Fig. 3 Current SSCI publications of men and women at each career stage

around one article annually and are thus about five times as productive. There is some evidence for decreasing returns: the more articles one has already published, the less every additional article seems to increase current productivity. It is because of these diminishing returns that we log prior publications when using them to explain current productivity.

This is descriptive evidence that political science is marked by accumulative advantage, as early productivity leads to later productivity. Last, Fig. 3 shows how this differs for men and women.

Figure 3 shows how the annual productivity of researchers with a $\mathrm{PhD}$ is higher than of researchers without a $\mathrm{PhD}$ and how the productivity of tenured professors is highest. Men publish significantly more early in their careers, while at later career stages, they are not significantly more productive than women at the same career stage. However, while Fig. 3 therefore indicates that men at later career stages are not much more productive annually, Fig. 4 shows how they have significantly more accumulated publications at later career stages.

Figure 4 shows how, with each career step, the accumulated publications of men move further away from those of women. Among early career researchers, men only have 20 percent $(0.30 / 0.25)$ more accumulated publications. Male postdocs, in contrast, already have 31 percent more accumulated publications than women at the same career stage, while tenured professors even have 46 percent more. Men thus do not publish much more annually, but because they publish a bit more early on and because early success brings later success, they become more and more productive compared to women. This is exactly what an accumulative advantage process looks like, where researchers become more productive when they have accumulated more experience in the past. The following sections show whether multivariate analyses confirm this, and which other influences seem to account for productivity.

\section{Who is more productive? RE models without control for prior productivity}

The RE models of Table 1 are still rather descriptive, as they show who is more productive, without accounting for prior productivity. They are set up as discussed in the methods section. 


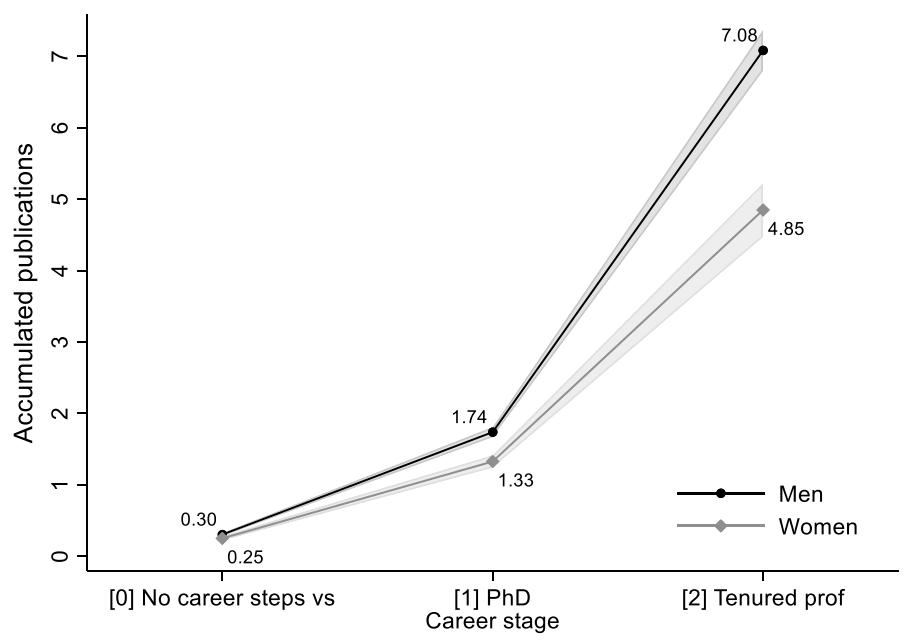

Fig. 4 Accumulated SSCI publications of men and women at each career stage

All regressions are centered around 1, which represents the typical number of annual publications in political science (about 0.23). All effects are therefore interpretable as follows: The constant of 0.97 in Model 1 shows that after a normal year (keep in mind that the dependent variable is lagged by one year), researchers publish close to what is typical for political science. Researchers with incomplete data publish 28 percent less, which means that the dummy variable captures the missing data. Substantively, Model 1 shows that across researchers and career stages, women annually publish 26 percent less than men do. But how much of this productivity disadvantage can be explained through career stages and other prior experience?

Model 2 shows that women at the same career stage, with the same social capital and prior education still publish 20 percent less annually than men do. It also shows that researchers with a $\mathrm{PhD}$ publish 49 percent more than those without a $\mathrm{PhD}$, while tenured professors publish 29 percent more. Those who spent twice as much time abroad are 16 percent more productive and those with a $\mathrm{PhD}$ from a foreign university are 106 percent (about twice) as productive than what is typical for political science. Researchers who moved more often are 12 percent more productive, having had more co-authors comes with 22 percent higher productivity and having been an interim professor comes with 33 percent less productivity. Researchers who had all of their career stages at a university of excellence are 19 percent more productive than those who had none of their career stages at a university of excellence.

Model 3 shows that researchers who have been funded by the DFG twice as often are 40 percent more productive. However, third party funding does not strongly change the influence of any other variable except that being a tenured professor becomes a lesser influence, which suggests that tenured professors publish more because they have DFG funding more often.

Model 4 adds the children variables, showing that children neither significantly explain who publishes more nor explain away the prior results. This means that the influence of career stages, international experience, social capital, elite status of one's university and third party funding are not mediated through the influence of having children. Because the men who have not responded to our question about children are especially unproductive, 
Table 1 RE, Who publishes more SSCI articles?

\begin{tabular}{|c|c|c|c|c|c|c|}
\hline & $\begin{array}{l}\text { (1) } \\
\text { productivity }\end{array}$ & $\begin{array}{l}\text { (2) } \\
\text { education }\end{array}$ & $\begin{array}{l}(3) \\
\text { money }\end{array}$ & $\begin{array}{l}\text { (4) } \\
\text { child }\end{array}$ & $\begin{array}{l}\text { (5) } \\
\text { women }\end{array}$ & $\begin{array}{l}(6) \\
\text { men }\end{array}$ \\
\hline Female mc & $\begin{array}{l}-0.26^{* *} \\
(-3.21)\end{array}$ & $\begin{array}{l}-0.20 * * \\
(-2.77)\end{array}$ & $\begin{array}{l}-0.19 * * \\
(-2.66)\end{array}$ & $\begin{array}{l}-0.26^{* *} \\
(-2.88)\end{array}$ & & \\
\hline \multicolumn{7}{|l|}{ [0] No career steps vs } \\
\hline [1] $\mathrm{PhD} \mathrm{mc}$ & & $\begin{array}{l}0.49 * * * \\
(8.37)\end{array}$ & $\begin{array}{l}0.49 * * * \\
(8.43)\end{array}$ & $\begin{array}{l}0.51 * * * \\
(8.90)\end{array}$ & $\begin{array}{l}0.47 * * * \\
(5.31)\end{array}$ & $\begin{array}{l}0.53 * * * \\
(7.19)\end{array}$ \\
\hline [2] Tenured prof mc & & $\begin{array}{l}0.29 * * \\
(2.98)\end{array}$ & $\begin{array}{l}0.17^{+} \\
(1.74)\end{array}$ & $\begin{array}{l}0.19^{+} \\
(1.95)\end{array}$ & $\begin{array}{l}0.23 \\
(1.30)\end{array}$ & $\begin{array}{l}0.17 \\
(1.47)\end{array}$ \\
\hline Months abroad (ln) mc & & $\begin{array}{l}0.16^{* * *} \\
(6.72)\end{array}$ & $\begin{array}{l}0.15^{* * *} \\
(6.63)\end{array}$ & $\begin{array}{l}0.15^{* * *} \\
(6.55)\end{array}$ & $\begin{array}{l}0.22 * * * \\
(5.71)\end{array}$ & $\begin{array}{l}0.12 * * * \\
(4.30)\end{array}$ \\
\hline PhD from abroad mc & & $\begin{array}{l}1.06 * * * \\
(7.22)\end{array}$ & $\begin{array}{l}1.06 * * * \\
(7.26)\end{array}$ & $\begin{array}{l}1.07 * * * \\
(7.29)\end{array}$ & $\begin{array}{l}0.68 * * * \\
(3.76)\end{array}$ & $\begin{array}{l}1.27 * * * \\
(6.18)\end{array}$ \\
\hline Mobility (ln) mc & & $\begin{array}{l}0.12 * \\
(2.14)\end{array}$ & $\begin{array}{l}0.11 * \\
(2.04)\end{array}$ & $\begin{array}{l}0.11 * \\
(2.08)\end{array}$ & $\begin{array}{l}0.11 \\
(1.20)\end{array}$ & $\begin{array}{l}0.10 \\
(1.50)\end{array}$ \\
\hline Co-authors (ln) mc & & $\begin{array}{l}0.22 * * * \\
(7.37)\end{array}$ & $\begin{array}{l}0.20 * * * \\
(6.84)\end{array}$ & $\begin{array}{l}0.20 * * * \\
(6.65)\end{array}$ & $\begin{array}{l}0.16 * * * \\
(3.40)\end{array}$ & $\begin{array}{l}0.22 * * * \\
(5.52)\end{array}$ \\
\hline Interim professor $(\ln ) \mathrm{mc}$ & & $\begin{array}{l}-0.33 * * * \\
(-3.51)\end{array}$ & $\begin{array}{l}-0.36^{* * *} \\
(-3.81)\end{array}$ & $\begin{array}{l}-0.35^{* * *} \\
(-3.75)\end{array}$ & $\begin{array}{l}-0.13 \\
(-0.72)\end{array}$ & $\begin{array}{l}-0.43 * * * \\
(-3.93)\end{array}$ \\
\hline University of excellence mc & & $\begin{array}{l}0.19 * \\
(2.36)\end{array}$ & $\begin{array}{l}0.17 * \\
(2.21)\end{array}$ & $\begin{array}{l}0.17 * \\
(2.13)\end{array}$ & $\begin{array}{l}0.09 \\
(0.66)\end{array}$ & $\begin{array}{l}0.19 * \\
(2.06)\end{array}$ \\
\hline DFG funding $(\ln ) \mathrm{mc}$ & & & $\begin{array}{l}0.40 * * * \\
(3.58)\end{array}$ & $\begin{array}{l}0.40 * * * \\
(3.61)\end{array}$ & $\begin{array}{l}0.32 \\
(1.52)\end{array}$ & $\begin{array}{l}0.45^{* * *} \\
(3.46)\end{array}$ \\
\hline Mother & & & & $\begin{array}{l}-0.15 \\
(-1.27)\end{array}$ & $\begin{array}{l}-0.15 \\
(-1.10)\end{array}$ & $\begin{array}{l}0.00 \\
(.)\end{array}$ \\
\hline Father & & & & $\begin{array}{l}-0.07 \\
(-0.64)\end{array}$ & $\begin{array}{l}0.00 \\
(.)\end{array}$ & $\begin{array}{l}-0.05 \\
(-0.48)\end{array}$ \\
\hline Woman child unknown & & & & $\begin{array}{l}-0.01 \\
(-0.07)\end{array}$ & $\begin{array}{l}-0.01 \\
(-0.10)\end{array}$ & $\begin{array}{l}0.00 \\
(.)\end{array}$ \\
\hline Man child unknown & & & & $\begin{array}{l}-0.24 * \\
(-2.57)\end{array}$ & $\begin{array}{l}0.00 \\
(.)\end{array}$ & $\begin{array}{l}-0.23 * \\
(-2.39)\end{array}$ \\
\hline Incomplete mc & $\begin{array}{l}-0.28^{*} \\
(-2.28)\end{array}$ & $\begin{array}{l}-0.31 * * \\
(-2.69)\end{array}$ & $\begin{array}{l}-0.32 * * \\
(-2.87)\end{array}$ & $\begin{array}{l}-0.31 * * \\
(-2.75)\end{array}$ & $\begin{array}{l}-0.10 \\
(-0.64)\end{array}$ & $\begin{array}{l}-0.40 * * \\
(-2.59)\end{array}$ \\
\hline Constant & $\begin{array}{l}0.97 * * * \\
(24.01)\end{array}$ & $\begin{array}{l}1.06 * * * \\
(26.82)\end{array}$ & $\begin{array}{l}1.06^{* * *} \\
(27.24)\end{array}$ & $\begin{array}{l}1.15^{* * *} \\
(19.69)\end{array}$ & $\begin{array}{l}0.97 * * * \\
(9.74)\end{array}$ & $\begin{array}{l}1.22 * * * \\
(16.82)\end{array}$ \\
\hline $\mathrm{r}^{2}$ within & 0.00 & 0.03 & 0.03 & 0.03 & 0.04 & 0.03 \\
\hline$r^{2}$ between & 0.01 & 0.21 & 0.22 & 0.23 & 0.20 & 0.23 \\
\hline $\mathrm{r}^{2}$ overall & 0.01 & 0.10 & 0.11 & 0.11 & 0.09 & 0.12 \\
\hline Observations & 16,853 & 16,853 & 16,853 & 16,853 & 5505 & 11,348 \\
\hline
\end{tabular}

$t$ statistics in parentheses; ${ }^{+} p<0.1, * p<0.05, * * p<0.01, * * * p<0.001 ; \ln =\log$ ged values; mc $=$ mean-centered

we use a dummy variable to capture a possible non-response bias. The $r^{2}$-between and $r^{2}$ within variation shows that all variables together explain 20 percent of variation between the productivity of researchers, but only 4 percent of productivity differences within the 
career of each researcher. The variables therefore explain much better who is more productive than someone else, rather than who is more productive than she or he usually is.

Model 5 and 6 run separate regressions for men and women. They show fairly similar effects for both, except that men seem to profit twice as much as women from having a foreign $\mathrm{PhD}$, having been at universities of excellence and receiving DFG funding, while at the same time being punished more when having acted as an interim professor.

\section{Who is more productive than what is typical? RE models controlling for prior productivity}

The following models are the same as before, except that they control for prior accumulated publications. They therefore illustrate not who publishes more, as the prior regressions did, but who publishes more than an average publication trajectory in political science would lead one to expect. Or in other words, the models show who publishes more than what would be expected for a given level of prior experience.

Model 1 shows how prior accumulated SSCI articles predict current publications significantly and substantially. Researchers who published twice as many SSCI articles in the past also publish 114 percent more articles in the present (plus 17 percent for prior nonSSCI articles). This means that having been a highly productive author of articles in the past predicts being a highly productive author of articles in the present. However, having published twice as many book chapters, edited volumes or gray literature in the past actually comes with lower current SSCI article productivity. This can be interpreted as two separate publishing cultures in political science. Those who publish articles do not publish books and vice versa. Most interestingly, however, note that the female effect is only 9 percent and insignificant after controlling for prior productivity. This stands in stark contrast to the very significant 26 percent productivity gap that Model 1 in Table 1 documented, when prior productivity was not controlled for. This means that women only publish 9 percent and insignificantly less than men when they have the same prior experience in publishing. However, women publish 26 percent less overall. Most of the lower female productivity can therefore be explained through a cumulative falling behind, rather than through lower productivity irrespective of prior experience.

Model 2 additionally shows that after having a $\mathrm{PhD}$, researchers publish 39 percent above a typical publication trajectory in political science. Scientists fall back on a typical publication trajectory (where past publications explain current publications) when they have a tenured professorship however. The positive effect of career stages is weaker than in Table 1's RE models, which did not control for prior productivity. This means that while researchers publish more with each successive career stage (Table 1), most of this is not due to career stages per se, but due to publication experience that comes with advanced career stages. Model 2 also shows that researchers with more months abroad, a $\mathrm{PhD}$ from abroad, more mobility and more co-authors publish more than a typical income trajectory suggests, while having been an interim professor is again negatively related to productivity, and having all degrees from a university of excellence means researchers publish 11 percent above a typical publication trajectory. With minus 13 percent, the female effect is slightly more negative and significant here. This means that women are hardly less productive because they are stuck at lower career stages, have less social capital, international experience or been to universities of excellence. Instead, women are mostly less productive because they have published less in the past, which deprives them of precious experience, 
which in turn hinders their publications in the future (compare Models 2 of Table 2 and of Table 1).

Model 3 shows that DFG grants come with 23 percent higher productivity. That the effect was almost twice as strong in the RE models that did not control for prior productivity means that DFG funding comes with an increase of articles by almost 40 percent (Model 3 in Table 1), which increases the productivity of researchers 23 percent above what is to be expected for a given level of prior publication experience. Model 4 introduces parenthood into the regressions. Because it is the most comprehensive model, Fig. 5 visualizes its relevant effect sizes.

Net of all other variables, mothers publish 19 and fathers 13 percent less than a typical long-term publication trajectory in political science would lead one to expect. Irrespective of whether they have children, women publish 19 percent less than men do. Since this effect is stronger in this model, which controls for children, we cannot explain the lower female productivity through children. Overall, prior productivity is again the strongest predictor of current productivity, followed by a $\mathrm{PhD}$ from abroad, having a $\mathrm{PhD}$ (and thus being at the postdoc career stage), followed by DFG funding. All variables together explain an impressive 51 percent of time-invariant productivity differences between the careers of researchers, but only 2 percent of the variation of productivity within the career of each researcher. Thus, the model explains much better who constantly publishes more than others, rather than when a researcher publishes more than she or he usually does.

Model 5 runs regressions for women and Model 6 for men only, showing how their productivity is related to different influences. It illustrates how prior productivity is a stronger predictor of future productivity for women than for men. Women who have published twice as many SSCI articles in the past publish 131 percent more articles currently, while for men the influence of past on current productivity is only 74 percent. Women who have published more monographs in the past publish 32 more SSCI articles currently. In contrast, men who published more monographs in the past publish 18 percent fewer SSCI articles presently. The data again shows that with increasing career stages, men increasingly outpublish women. After having a $\mathrm{PhD}$, men publish 50 percent more, compared to women's 18 percent. When women are tenured professors, they even publish 33 percent less than what is a typical political science publication trajectory, while tenured male professors exceed an average trajectory by 20 percent (albeit statistically insignificantly). While months abroad seem to help women twice as much as men, a $\mathrm{PhD}$ from abroad is much more related to higher publications for men. A manual inspection of the data shows that this is because men have PhDs from more prestigious foreign institutions. Mobility in turn is much more related to publications for men, so is having more co-authors, while being an interim professor is similarly detrimental for both. Men with diplomas from a university of excellence publish 13 percent above a typical trajectory, while women who have been at universities of excellence do not publish significantly more. And while men who have received DFG funding publish 32 percent more, women do not publish more after having been funded by the DFG. Last, we now see that mothers are less productive compared to childless women, while fathers are not significantly less productive than childless men.

Generally, the random effects models of Table 1, which do not control for prior productivity, yield similar but stronger results than the random effects models that do control for prior productivity of Table 2, which we have just discussed. This means that whatever helps researchers to publish more than a typical publication trajectory in political science also helps them to be more productive generally. However, while the models so far show who is more productive than others, they cannot show why a researcher publishes more or less than she or he normally does. This is what the following fixed effects models show. 
Table 2 RE, Who publishes more than an average publication trajectory?

\begin{tabular}{|c|c|c|c|c|c|c|}
\hline & $\begin{array}{l}\text { (1) } \\
\text { productivity }\end{array}$ & $\begin{array}{l}\text { (2) } \\
\text { education }\end{array}$ & $\begin{array}{l}(3) \\
\text { money }\end{array}$ & $\begin{array}{l}\text { (4) } \\
\text { child }\end{array}$ & $\begin{array}{l}\text { (5) } \\
\text { women }\end{array}$ & $\begin{array}{l}(6) \\
\text { men }\end{array}$ \\
\hline Prior SSCI articles (ln) mc & $\begin{array}{l}1.14 * * * \\
(17.78)\end{array}$ & $\begin{array}{l}0.94 * * * \\
(14.15)\end{array}$ & $\begin{array}{l}0.90 * * * \\
(13.57)\end{array}$ & $\begin{array}{l}0.91 * * * \\
(13.58)\end{array}$ & $\begin{array}{l}1.31 * * * \\
(8.47)\end{array}$ & $\begin{array}{l}0.74 * * * \\
(10.65)\end{array}$ \\
\hline Prior monographs (ln) mc & $\begin{array}{l}-0.02 \\
(-0.42)\end{array}$ & $\begin{array}{l}-0.06 \\
(-0.99)\end{array}$ & $\begin{array}{l}-0.07 \\
(-1.14)\end{array}$ & $\begin{array}{l}-0.07 \\
(-1.08)\end{array}$ & $\begin{array}{l}0.32 * \\
(2.05)\end{array}$ & $\begin{array}{l}-0.18 * * \\
(-2.87)\end{array}$ \\
\hline Prior book chapters (ln) mc & $\begin{array}{l}-0.07^{+} \\
(-1.96)\end{array}$ & $\begin{array}{l}-0.16^{* * *} \\
(-4.19)\end{array}$ & $\begin{array}{l}-0.16^{* * * *} \\
(-4.16)\end{array}$ & $\begin{array}{l}-0.16^{* * *} \\
(-4.01)\end{array}$ & $\begin{array}{l}-0.06 \\
(-0.87)\end{array}$ & $\begin{array}{l}-0.18 * * * \\
(-3.90)\end{array}$ \\
\hline Prior non-SSCI articles (ln) mc & $\begin{array}{l}0.17 * * * \\
(4.14)\end{array}$ & $\begin{array}{l}0.14 * * * \\
(3.37)\end{array}$ & $\begin{array}{l}0.14^{* * *} \\
(3.38)\end{array}$ & $\begin{array}{l}0.14^{* * *} \\
(3.36)\end{array}$ & $\begin{array}{l}0.11 \\
(1.59)\end{array}$ & $\begin{array}{l}0.15^{* *} \\
(2.81)\end{array}$ \\
\hline Prior edited volumes (ln) mc & $\begin{array}{l}-0.36^{* * * *} \\
(-6.49)\end{array}$ & $\begin{array}{l}-0.33 * * * \\
(-5.60)\end{array}$ & $\begin{array}{l}-0.35 * * * \\
(-5.83)\end{array}$ & $\begin{array}{l}-0.34 * * * \\
(-5.74)\end{array}$ & $\begin{array}{l}-0.37 * * * \\
(-3.40)\end{array}$ & $\begin{array}{l}-0.34 * * * \\
(-4.63)\end{array}$ \\
\hline Prior gray literature $(\mathrm{ln}) \mathrm{mc}$ & $\begin{array}{l}-0.08^{*} \\
(-2.24)\end{array}$ & $\begin{array}{l}-0.14 * * * \\
(-3.75)\end{array}$ & $\begin{array}{l}-0.14 * * * \\
(-3.73)\end{array}$ & $\begin{array}{l}-0.13 * * * \\
(-3.72)\end{array}$ & $\begin{array}{l}-0.14^{*} \\
(-2.24)\end{array}$ & $\begin{array}{l}-0.13 * * \\
(-2.97)\end{array}$ \\
\hline Female mc & $\begin{array}{l}-0.09 \\
(-1.50)\end{array}$ & $\begin{array}{l}-0.13^{*} \\
(-2.22)\end{array}$ & $\begin{array}{l}-0.13^{*} \\
(-2.18)\end{array}$ & $\begin{array}{l}-0.19 * \\
(-2.26)\end{array}$ & & \\
\hline \multicolumn{7}{|l|}{ [0] No career steps vs } \\
\hline [1] $\mathrm{PhD} \mathrm{mc}$ & & $\begin{array}{l}0.39 * * * \\
(6.70)\end{array}$ & $\begin{array}{l}0.40^{* * *} \\
(6.83)\end{array}$ & $\begin{array}{l}0.42 * * * \\
(7.34)\end{array}$ & $\begin{array}{l}0.18^{+} \\
(1.81)\end{array}$ & $\begin{array}{l}0.50 * * * \\
(6.77)\end{array}$ \\
\hline [2] Tenured prof mc & & $\begin{array}{l}0.11 \\
(1.04)\end{array}$ & $\begin{array}{l}0.06 \\
(0.57)\end{array}$ & $\begin{array}{l}0.09 \\
(0.85)\end{array}$ & $\begin{array}{l}-0.33^{+} \\
(-1.77)\end{array}$ & $\begin{array}{l}0.20 \\
(1.64)\end{array}$ \\
\hline Months abroad (ln) mc & & $\begin{array}{l}0.09 * * * \\
(5.00)\end{array}$ & $\begin{array}{l}0.09 * * * \\
(5.12)\end{array}$ & $\begin{array}{l}0.09 * * * \\
(5.02)\end{array}$ & $\begin{array}{l}0.13 * * * \\
(5.41)\end{array}$ & $\begin{array}{l}0.07 * * \\
(2.93)\end{array}$ \\
\hline $\mathrm{PhD}$ from abroad $\mathrm{mc}$ & & $\begin{array}{l}0.58 * * * \\
(5.03)\end{array}$ & $\begin{array}{l}0.59 * * * \\
(5.11)\end{array}$ & $\begin{array}{l}0.59 * * * \\
(5.13)\end{array}$ & $\begin{array}{l}0.17 \\
(1.12)\end{array}$ & $\begin{array}{l}0.80 * * * \\
(5.04)\end{array}$ \\
\hline Mobility (ln) mc & & $\begin{array}{l}0.09 * \\
(2.19)\end{array}$ & $\begin{array}{l}0.09 * \\
(2.13)\end{array}$ & $\begin{array}{l}0.09 * \\
(2.17)\end{array}$ & $\begin{array}{l}0.02 \\
(0.29)\end{array}$ & $\begin{array}{l}0.12 * \\
(2.19)\end{array}$ \\
\hline Co-authors (ln) mc & & $\begin{array}{l}0.22 * * * \\
(7.49)\end{array}$ & $\begin{array}{l}0.22^{* * *} \\
(7.40)\end{array}$ & $\begin{array}{l}0.22 * * * \\
(7.34)\end{array}$ & $\begin{array}{l}0.09^{+} \\
(1.73)\end{array}$ & $\begin{array}{l}0.27 * * * \\
(7.37)\end{array}$ \\
\hline Interim professor (ln) mc & & $\begin{array}{l}-0.31 * * \\
(-3.26)\end{array}$ & $\begin{array}{l}-0.32 * * * \\
(-3.36)\end{array}$ & $\begin{array}{l}-0.31 * * * \\
(-3.34)\end{array}$ & $\begin{array}{l}-0.37 * \\
(-2.03)\end{array}$ & $\begin{array}{l}-0.31 * * \\
(-2.81)\end{array}$ \\
\hline University of excellence mc & & $\begin{array}{l}0.11^{+} \\
(1.85)\end{array}$ & $\begin{array}{l}0.10^{+} \\
(1.76)\end{array}$ & $\begin{array}{l}0.10^{+} \\
(1.67)\end{array}$ & $\begin{array}{l}0.04 \\
(0.42)\end{array}$ & $\begin{array}{l}0.13^{+} \\
(1.82)\end{array}$ \\
\hline DFG funding $(\ln ) \mathrm{mc}$ & & & $\begin{array}{l}0.23^{*} \\
(2.37)\end{array}$ & $\begin{array}{l}0.23 * \\
(2.39)\end{array}$ & $\begin{array}{l}0.04 \\
(0.20)\end{array}$ & $\begin{array}{l}0.32 * * \\
(2.91)\end{array}$ \\
\hline Mother & & & & $\begin{array}{l}-0.19^{+} \\
(-1.84)\end{array}$ & $\begin{array}{l}-0.29 * \\
(-2.27)\end{array}$ & \\
\hline Father & & & & $\begin{array}{l}-0.13 \\
(-1.48)\end{array}$ & & $\begin{array}{l}-0.10 \\
(-1.03)\end{array}$ \\
\hline Woman child unknown & & & & $\begin{array}{l}-0.02 \\
(-0.21)\end{array}$ & $\begin{array}{l}-0.09 \\
(-0.88)\end{array}$ & \\
\hline Man child unknown & & & & $\begin{array}{l}-0.19 * \\
(-2.56)\end{array}$ & & $\begin{array}{l}-0.17 * \\
(-2.18)\end{array}$ \\
\hline Incomplete mc & $\begin{array}{l}-0.19 * \\
(-2.52)\end{array}$ & $\begin{array}{l}-0.25 * * \\
(-3.29)\end{array}$ & $\begin{array}{l}-0.26^{* * *} \\
(-3.40)\end{array}$ & $\begin{array}{l}-0.25^{* *} \\
(-3.18)\end{array}$ & $\begin{array}{l}-0.01 \\
(-0.07)\end{array}$ & $\begin{array}{l}-0.33^{* *} \\
(-3.21)\end{array}$ \\
\hline
\end{tabular}


Table 2 (continued)

\begin{tabular}{|c|c|c|c|c|c|c|}
\hline \multirow[t]{2}{*}{ Constant } & $1.03 * * *$ & $1.02 * * *$ & $1.02^{* * * *}$ & $1.12 * * *$ & $1.09 * * *$ & $1.16^{* * * *}$ \\
\hline & $(34.81)$ & (35.24) & (35.33) & $(22.86)$ & (11.18) & (19.41) \\
\hline $\mathrm{r}^{2}$ within & 0.01 & 0.02 & 0.02 & 0.02 & 0.02 & 0.02 \\
\hline $\mathrm{r}^{2}$ between & 0.53 & 0.51 & 0.51 & 0.51 & 0.56 & 0.49 \\
\hline $\mathrm{r}^{2}$ overall & 0.19 & 0.20 & 0.20 & 0.20 & 0.20 & 0.21 \\
\hline Observations & 16,853 & 16,853 & 16,853 & 16,853 & 5505 & 11,348 \\
\hline
\end{tabular}

$t$ statistics in parentheses; ${ }^{+} p<0.1,{ }^{*} p<0.05,{ }^{* *} p<0.01,{ }^{* * *} p<0.001 ; \ln =\operatorname{logged}$ values; mc $=$ mean-centered

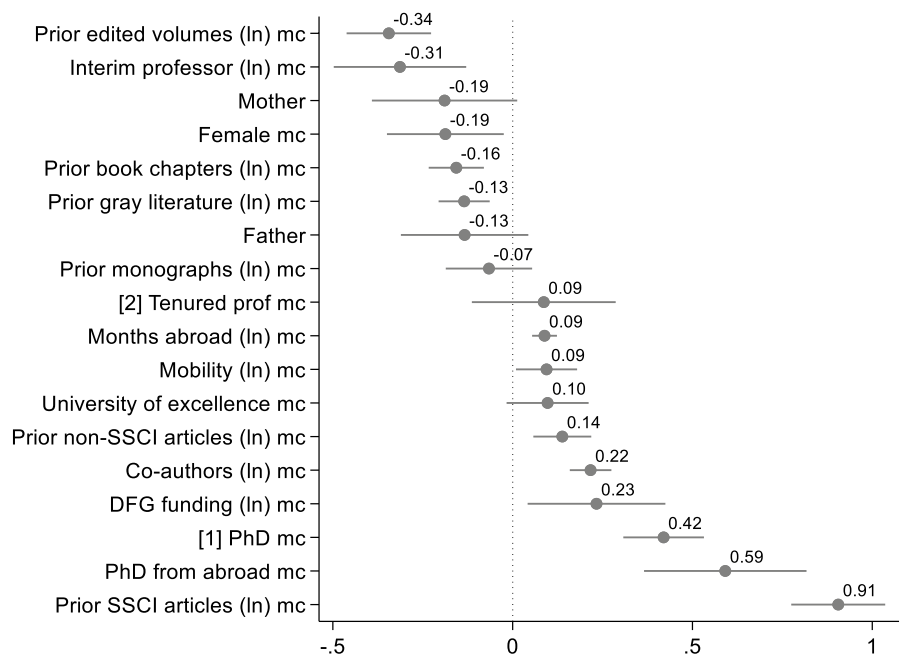

Fig. 5 Model 4 (RE after control for prior productivity) with all effects

\section{When is a researcher more productive than usually? FE models controlling for prior productivity}

In the following, we explain current publications through changes within the career of individual researchers. Thus, we do not show who publishes more than others, but under which conditions an individual researcher publishes more than she or he usually does.

Model 1 of Table 3 shows that within the career of each researcher, prior performance predicts future performance less than in the previous random effects models. This means that the effects of prior on current productivity were largely due to a between or population effect: Researchers who published twice as much as others in the past also publish twice as much as others currently. But the same researcher only publishes 12 percent more SSCI articles currently when having published twice as many articles in the past. Differences in research productivity are therefore largely differences between researchers, rather than productivity differences within the careers of each individual researcher. 
Table 3 FE, Who is more productive than what would be expected based on publications so far?

\begin{tabular}{|c|c|c|c|c|c|c|}
\hline & $\begin{array}{l}\text { (1) } \\
\text { productivity }\end{array}$ & $\begin{array}{l}\text { (2) } \\
\text { education }\end{array}$ & $\begin{array}{l}(3) \\
\text { money }\end{array}$ & $\begin{array}{l}\text { (4) } \\
\text { child }\end{array}$ & $\begin{array}{l}\text { (5) } \\
\text { women }\end{array}$ & $\begin{array}{l}(6) \\
\text { men }\end{array}$ \\
\hline Prior SSCI articles (ln) mc & $\begin{array}{l}0.12 \\
(1.57)\end{array}$ & $\begin{array}{l}-0.02 \\
(-0.26)\end{array}$ & $\begin{array}{l}-0.07 \\
(-0.99)\end{array}$ & $\begin{array}{l}-0.08 \\
(-1.01)\end{array}$ & $\begin{array}{l}0.05 \\
(0.31)\end{array}$ & $\begin{array}{l}-0.14^{+} \\
(-1.68)\end{array}$ \\
\hline Prior monographs $(\ln ) \mathrm{mc}$ & $\begin{array}{l}0.07 \\
(0.81)\end{array}$ & $\begin{array}{l}-0.14^{+} \\
(-1.66)\end{array}$ & $\begin{array}{l}-0.15^{+} \\
(-1.82)\end{array}$ & $\begin{array}{l}-0.15^{+} \\
(-1.84)\end{array}$ & $\begin{array}{l}0.11 \\
(0.61)\end{array}$ & $\begin{array}{l}-0.21^{*} \\
(-2.15)\end{array}$ \\
\hline Prior book chapters $(\ln ) \mathrm{mc}$ & $\begin{array}{l}0.08 \\
(1.52)\end{array}$ & $\begin{array}{l}-0.08 \\
(-1.50)\end{array}$ & $\begin{array}{l}-0.08 \\
(-1.49)\end{array}$ & $\begin{array}{l}-0.08 \\
(-1.48)\end{array}$ & $\begin{array}{l}-0.04 \\
(-0.36)\end{array}$ & $\begin{array}{l}-0.09 \\
(-1.42)\end{array}$ \\
\hline Prior non-SSCI articles (ln) mc & $\begin{array}{l}0.41 * * * \\
(6.45)\end{array}$ & $\begin{array}{l}0.31 * * * \\
(4.85)\end{array}$ & $\begin{array}{l}0.31 * * * \\
(4.83)\end{array}$ & $\begin{array}{l}0.31 * * * \\
(4.83)\end{array}$ & $\begin{array}{l}0.34 * * * \\
(3.38)\end{array}$ & $\begin{array}{l}0.30 * * * \\
(3.59)\end{array}$ \\
\hline Prior edited volumes $(\ln ) \mathrm{mc}$ & $\begin{array}{l}-0.39 * * * \\
(-5.20)\end{array}$ & $\begin{array}{l}-0.31 * * * \\
(-3.83)\end{array}$ & $\begin{array}{l}-0.34 * * * \\
(-4.18)\end{array}$ & $\begin{array}{l}-0.34 * * * \\
(-4.18)\end{array}$ & $\begin{array}{l}-0.28 * \\
(-2.16)\end{array}$ & $\begin{array}{l}-0.36 * * * \\
(-3.54)\end{array}$ \\
\hline Prior gray literature $(\ln ) \mathrm{mc}$ & $\begin{array}{l}0.05 \\
(1.06)\end{array}$ & $\begin{array}{l}-0.08 \\
(-1.41)\end{array}$ & $\begin{array}{l}-0.07 \\
(-1.38)\end{array}$ & $\begin{array}{l}-0.08 \\
(-1.40)\end{array}$ & $\begin{array}{l}-0.13 \\
(-1.36)\end{array}$ & $\begin{array}{l}-0.06 \\
(-0.92)\end{array}$ \\
\hline \multicolumn{7}{|l|}{ [0] No career steps vs } \\
\hline [1] $\mathrm{PhD} \mathrm{mc}$ & & $\begin{array}{l}0.52 * * * \\
(7.50)\end{array}$ & $\begin{array}{l}0.54 * * * \\
(7.79)\end{array}$ & $\begin{array}{l}0.54 * * * \\
(7.93)\end{array}$ & $\begin{array}{l}0.36^{* *} \\
(3.16)\end{array}$ & $\begin{array}{l}0.60 * * * \\
(6.87)\end{array}$ \\
\hline [2] Tenured prof mc & & $\begin{array}{l}0.35 * * \\
(3.04)\end{array}$ & $\begin{array}{l}0.30 * * \\
(2.59)\end{array}$ & $\begin{array}{l}0.30 * * \\
(2.59)\end{array}$ & $\begin{array}{l}0.06 \\
(0.31)\end{array}$ & $\begin{array}{l}0.36^{*} \\
(2.53)\end{array}$ \\
\hline Months abroad (ln) mc & & $\begin{array}{l}0.16^{* * *} \\
(4.39)\end{array}$ & $\begin{array}{l}0.16^{* * *} \\
(4.39)\end{array}$ & $\begin{array}{l}0.16 * * * \\
(4.37)\end{array}$ & $\begin{array}{l}0.22 * * \\
(3.05)\end{array}$ & $\begin{array}{l}0.15 * * * \\
(3.54)\end{array}$ \\
\hline Mobility (ln) mc & & $\begin{array}{l}0.20 * \\
(2.46)\end{array}$ & $\begin{array}{l}0.21 * \\
(2.51)\end{array}$ & $\begin{array}{l}0.21 * \\
(2.51)\end{array}$ & $\begin{array}{l}0.25 \\
(1.50)\end{array}$ & $\begin{array}{l}0.18^{+} \\
(1.91)\end{array}$ \\
\hline Co-authors (ln) mc & & $\begin{array}{l}0.24 * * * \\
(4.74)\end{array}$ & $\begin{array}{l}0.24 * * * \\
(4.64)\end{array}$ & $\begin{array}{l}0.24 * * * \\
(4.58)\end{array}$ & $\begin{array}{l}0.12 \\
(1.59)\end{array}$ & $\begin{array}{l}0.29 * * * \\
(4.03)\end{array}$ \\
\hline Interim professor $(\mathrm{ln}) \mathrm{mc}$ & & $\begin{array}{l}-0.22 * \\
(-2.22)\end{array}$ & $\begin{array}{l}-0.23^{*} \\
(-2.32)\end{array}$ & $\begin{array}{l}-0.23^{*} \\
(-2.32)\end{array}$ & $\begin{array}{l}-0.04 \\
(-0.19)\end{array}$ & $\begin{array}{l}-0.31 * * \\
(-2.63)\end{array}$ \\
\hline University of excellence mc & & $\begin{array}{l}0.05 \\
(0.24)\end{array}$ & $\begin{array}{l}0.02 \\
(0.11)\end{array}$ & $\begin{array}{l}0.03 \\
(0.13)\end{array}$ & $\begin{array}{l}0.44 \\
(1.11)\end{array}$ & $\begin{array}{l}-0.12 \\
(-0.51)\end{array}$ \\
\hline DFG funding $(\ln ) \mathrm{mc}$ & & & $\begin{array}{l}0.33 * * \\
(2.86)\end{array}$ & $\begin{array}{l}0.33 * * \\
(2.87)\end{array}$ & $\begin{array}{l}0.04 \\
(0.17)\end{array}$ & $\begin{array}{l}0.43 * * \\
(3.27)\end{array}$ \\
\hline Mother & & & & $\begin{array}{l}-0.05 \\
(-0.41)\end{array}$ & $\begin{array}{l}-0.06 \\
(-0.44)\end{array}$ & \\
\hline Father & & & & $\begin{array}{l}0.04 \\
(0.32)\end{array}$ & & $\begin{array}{l}0.05 \\
(0.41)\end{array}$ \\
\hline Incomplete mc & $\begin{array}{l}-1.41 \\
(-1.45)\end{array}$ & $\begin{array}{l}-1.22 \\
(-1.28)\end{array}$ & $\begin{array}{l}-1.22 \\
(-1.32)\end{array}$ & $\begin{array}{l}-1.20 \\
(-1.31)\end{array}$ & $\begin{array}{l}0.02 \\
(0.05)\end{array}$ & $\begin{array}{l}-1.33 \\
(-1.30)\end{array}$ \\
\hline Constant & $\begin{array}{l}1.00 * * * \\
(4.41 \mathrm{e}+08)\end{array}$ & $\begin{array}{l}1.00 * * * \\
(3.46 \mathrm{e}+08)\end{array}$ & $\begin{array}{l}1.00 * * * \\
(3.52 \mathrm{e}+08)\end{array}$ & $\begin{array}{l}1.00 * * * \\
(37.66)\end{array}$ & $\begin{array}{l}0.90 * * * \\
(17.23)\end{array}$ & $\begin{array}{l}1.08 * * * \\
(30.97)\end{array}$ \\
\hline $\mathrm{r}^{2}$ within & 0.02 & 0.04 & 0.04 & 0.04 & 0.04 & 0.04 \\
\hline $\mathrm{r}^{2}$ between & 0.03 & 0.11 & 0.10 & 0.10 & 0.15 & 0.09 \\
\hline $\mathrm{r}^{2}$ overall & 0.03 & 0.07 & 0.07 & 0.07 & 0.07 & 0.07 \\
\hline Observations & 16,853 & 16,853 & 16,853 & 16,853 & 5505 & 11,348 \\
\hline
\end{tabular}

$t$ statistics in parentheses; ${ }^{+} p<0.1, * p<0.05, * * p<0.01, * * * p<0.001 ; \ln =$ logged values; mc $=$ mean-centered 
Model 2 shows that the same researcher publishes 52 percent more as a postdoc and 35 percent more as a tenured professor, compared to what would be expected based on her or his personal publication trajectory. This means that reaching higher career stages seems to have a positive effect on productivity, which cannot be reduced to the higher publication experience that comes with later career stages. Every doubling of months abroad increases the productivity of the same researcher by 16 percent, general mobility by 20 percent, coauthors by 24 percent and having been an interim professor more often decreases the publications of the same researcher by 22 percent. Strikingly, getting a larger share of degrees from so-called universities of excellence does not help the same researcher to exceed her or his publication trajectory. That the effect has been positive in the RE models but not here in the FE models, shows that universities of excellence attract more productive researchers, but do not make the same researcher more productive than her or his prior experience, career stage, international experience and mobility suggest anyways.

Model 3 shows that the same researcher publishes 33 percent above her or his typical publication trajectory after having been funded by the DFG twice as often. Comparing this to the previous RE models shows that funding not only goes to researchers who are more productive, but that it also makes the same researcher more productive than she or he would have been without funding. Note how this is different from the effects of universities of excellence: yes, more productive researchers have been disproportionally at universities of excellence, but no, the same researcher is not more productive after having been there. Thus, while any effect of universities of excellence seems to be due to a population effect (more productive researchers are at universities of excellence), the effect of DFG funding seems to be an actual effect on the publications of researchers (DFG funding increases the publications of the same researcher).

Model 4 shows that neither becoming a mother nor a father significantly changes the publication trajectory of the same researcher. Contrasting this to the preceding models suggests a dominant between effect: Those who have been a mother or father all along are a less productive group, relative to what would be expected for their career stage, international experience, social capital and funding. But the same researcher does not publish significantly less than would be expected after having children. Separate between-effects regressions (not shown here) confirm this: Mothers, as a group, publish 39 percent less than what is typical in political science for a given level of prior experience, career stages and DFG funding. Differently from this, fathers as a group (irrespective of whether or not a researcher is yet a father) do not publish significantly less than the group of childless men. It is therefore not becoming a mother that makes a researcher less productive. Instead, the group of mothers are less productive than the group of childless women, irrespectively of the influence of childbirth on the career of the same researcher. In others words, those women who eventually have children are less productive regardless of whether they currently have a child; but a productive woman does not lose her productivity after having a child. This suggests a selection effect of less productive women into motherhood, rather than a causal effect of childbirth on the productivity of the same woman.

Models 5 and 6 calculate separate FE models for men and women, but hardly deviate from the conclusions that the prior RE models suggest. They again show that the same man increases his publications much more with each career step than the same woman does. However, a typical woman profits more from months abroad. The same man also profits about three times as much from past co-authors, but is punished much more when doing interim professorships. Strikingly, the same man publishes 43 percent above his long-run publication trajectory after having been funded by the DFG twice as often, while the same woman does not publish more after receiving DFG funding. 


\section{Robustness tests}

\section{Different coding of universities of excellence}

We have coded the influence of being at a university of excellence through the share of degrees a researcher has obtained from every university that was a university of excellence at least once. However, it is possible that only some career stages at universities of excellence increase productivity. We therefore separately estimated the effect of having a $\mathrm{PhD}$ from a university of excellence, of having been there as an assistant professor or having gotten tenure there. After adjusting for prior productivity, we find that those who have a $\mathrm{PhD}$ from a university of excellence publish 20 percent more than those who have a $\mathrm{PhD}$ that is not from a university of excellence and they publish 29 percent more than their own publication trajectory would suggest when they have been at a university of excellence, rather than having gotten their $\mathrm{PhD}$ from another university. However, we find that those who have a habilitation from a university of excellence publish less than others and less than they would have in the absence of such a habilitation. In addition, being a tenured professor at a university of excellence neither lets researchers publish more than other tenured professors nor does it let them publish more than they would have if they had been employed by another university (see Online Annex heading "Different coding of universities of excellence", Table A1 for RE and A2 for FE models).

\section{Monographs rather than $\mathrm{SSCl}$ articles}

In separate regressions, we checked whether our results hold when defining productivity as the publication of monographs rather than SSCI articles (see Online Annex heading: "Monographs rather than SSCI articles", Tables A3 to A5). Some covariates, such as "months abroad" or "PhD abroad", may reflect socialization that leads to publishing more SSCI-articles, rather than other measures of productivity. Therefore, we use separate models that explain the publication of monographs as well as non-SSCI-articles (next section). The RE regressions that explain book publications in the Online Annex confirm the cumulative falling behind of women. The first regression, which does not control for prior publications, shows that women publish 31 percent fewer monographs than men overall, almost the same as their productivity disadvantage for SSCI articles. Accounting for all covariates only reduces the female disadvantage to 25 percent. Because political scientists write fewer books than SSCI articles, we have fewer cases to work with, so other variables are insignificant, except that having a $\mathrm{PhD}$ comes with more monographs, while having a $\mathrm{PhD}$ from abroad comes with fewer.

The RE regressions that do control for prior productivity show that, given the same prior publication experience, women publish only 19 percent fewer books (rather than 31 percent fewer over their entire career). This means that women publish 19 percent fewer books each year with the same level of experience, but over their career this accumulates to a 31 percent lower annual productivity, as early experience in publishing leads to later productivity. The other noteworthy results are that having been at universities of excellence is unrelated to the production of monographs and DFG funding actually decreases monographs 19 percent below what would be expected for a given level of experience. Again, children do not seem to influence book production strongly, so we cannot conclude that women author fewer monographs because they have children, but rather, that they are less productive because they fall behind as they author fewer monographs early in their career. 
Last, the FE regressions show that the same researcher tends to stop writing books when having done so in the past, which can be interpreted as an effect of "having one's book written." In other words, when researchers have written a book in the past, they may stop doing so in the future and only recommence publishing books when their last book has been out for a while.

Not many of the variables strongly predict book publications, which is an important result in itself, insofar as having been to universities of excellence, DFG funding and having children do not depress or increase book publications of an individual researcher above or below what is typical for him or her. Overall, these results therefore support the main conclusions that we can draw when using SSCI articles as a measure of productivity.

\section{Non-SSCl articles}

We then repeated all calculations by using non-SSCI rather than SSCI articles (see Online Annex heading: "Non-SSCI rather than SSCI articles", Tables A6 to A8). This again confirms our main conclusions. Women publish 31 percent fewer non-SSCI articles than men, which only reduces to 28 percent less after including all controls. However, accounting for prior productivity reduces the female disadvantage to a mere 17 percent. While having written more non-SSCI articles in the past strongly predicts current non-SSCI publications when contrasting different researchers, the opposite is true within the career of each researchers. Thus, researchers who have written more non-SSCI articles in the past than others also publish more in the future. But the same researcher tends to write fewer nonSSCI articles when having done so more in the past. Not many other variables strongly influence the publication of non-SSCI articles, neither when comparing different researchers, nor when comparing within the career of the same researcher over time. Thus, looking at non-SSCI articles again confirms that women publish less because they start publishing less early in their careers, which leads to a large disadvantage over time. Not much else (including children) explains why women (or men) publish fewer non-SSCI articles or, for that matter, why researchers generally publish non-SSCI articles.

\section{Actually taking care of children rather than having them}

While we generally found that children do not have a strong influence on publications, it is possible that taking care of them, rather than just having them, is what strongly influences publications (Jaksztat, 2017: p. 349). We have asked our respondents who mostly takes care of children in their relationship. Respondents could answer on a scale ranging from "much less responsible," over "about equal" to "much more responsible." While we did find that women claim childcare responsibility more often (mean $=2.6$ vs. 1.3 for men), we surprisingly did not find that this strongly influences the results. This is because there is no clear effect of taking care of children on publications, neither for men, nor for women. At the same time, a negative female effect remains, even after controlling for who takes care of children (see heading "Taking account of intensity of childcare", Table A9 in the Online Annex). 


\section{Age of children}

Some have claimed that children do not generally depress the productivity of women, but that only young children do (Kyvik, 1990: p. 157; Kyvik \& Teigen, 1996: p. 68f.). We therefore tested whether children of different ages depress productivity differently. Our results show that women whose children are one year old indeed publish less than comparable men. However, the effect does not exist for any other age of children and disappears after including controls. At the same time, women with 17-year old children publish more than men and women generally still publish less than men. While not all of these effects are significant, we therefore conclude that children do not systematically depress female productivity, except directly after childbirth, which is not enough of an effect to explain why women generally publish less (see heading "Taking account of child age", Table A10 in the Online Annex).

\section{Counting every publication as single-authored}

Finally, it is possible that how we adjusted for co-authorship biases our data. We therefore counted every article as single-authored, as e.g. Google scholar does. However, our conclusions also hold under this condition. Namely, while researchers publish 0.37 articles annually (when counting every article as single-authored), women publish 0.07 fewer articles annually (about 20 percent). This effect is somewhat reduced by accounting for prior experience. Being a postdoc, having spent more months abroad or having a $\mathrm{PhD}$ from abroad, as well as more mobility, co-authors and DFG funding all increase publications, while having been an interim professor has a negative effect. Universities of excellence attract slightly more productive researchers, but do not make the same researcher more productive, while being a parent has no effect. Being a tenured professor has no effect, while becoming a tenured professor increases productivity within the career of the same researcher. This latter effect might mean that tenured professors increasingly publish with others (given that no effect existed when we discounted co-authored publications). For these results, see heading "Counting every article as single-authored", Table A11 in the Online Annex.

\section{Discussion}

We now show what our results imply for the open theoretical questions discussed in the introduction. We also compare our findings to another discipline, sociology, and discuss implications for policy that tries to promote female careers as well as the implication of our results for the success of third party funding. Last, we discuss implications for how individual researchers can have a successful career. 


\section{Human capital}

Existing studies suggest that prior productivity is a good predictor of future productivity (Lee, 2019: p. 1500; Lindahl et al., 2020: p. 326). We can confirm this as researchers who published twice as many SSCI articles in the past also publish twice as many articles currently (Model 1 of Table 2). Thus, past productivity is an almost perfect predictor of current productivity when comparing researchers: those who were more productive in the past are also more productive than others in the future. Within the career of each researcher however, having published twice as many SSCI articles in the past does not lead to publishing more in the future. This means that while early productivity is a good predictor of later productivity when comparing different researchers, within the career of the same researcher, more publications in the past do not consequently lead to more publications in the future. Fittingly, we also do not find that the same researcher becomes ever-more productive with career stages (similarly, cf. Jadidi et al., 2018: pp. 1750011-7). Instead, productivity seems to increase until tenure and then to decline slightly, relative to one's time as a postdoc (while staying above the level one had as a $\mathrm{PhD}$ student). That productivity declines with tenure, relative to one's time as a postdoc, may be because tenured professors have more duties that keep them from publishing or because tenure itself decreases the incentive to publish.

\section{Duration, quality and social capital of one's education}

It has been much discussed whether grouping universities into normal universities on the one side and "universities of excellence" on the other bears any semblance to actual productivity differences. We have found that indeed, researchers from universities of excellence publish at most 19 percent more than others and at most 11 percent more than an average publication trajectory would suggest. Importantly however, the same researcher is not more productive after having a higher share of her or his degrees from a university of excellence. An exception to this is found in our robustness tests, which showed that universities of excellence produce more productive postdocs but not more productive tenured professors. Overall, we therefore found what Carayol and Matt, (2006: p. 60) call an "intrinsic ability" effect, where some departments attract more "intrinsically able" researchers than others. But with the exception of postdocs, we could not find what Carayol and Matt call a "departmental effect", which would mean the same researcher becomes more productive after having been at an elite department. This contradicts classical findings from the US, which show that better departments do increase a scholar's productivity (Long, 1978: p. 902). However, it fits with Merton's, (1968: p. 62) idea that "centers of demonstrated scientific excellence are allocated far larger resources for investigation than centers which have yet to make their mark. In turn, their prestige attracts a disproportionate share of the truly promising graduate students." It also fits studies arguing that allocating "subsidies to some departments appears to be useless: it may attract the more active researchers to the richer departments, but does not increase their output when taking into account authors fixed effects" (Dubois et al., 2014: p. 1687; in contrast, cf. Möller et al., 2016: p. 2235; in support of this view, cf. García-Suaza et al., 2020: p. 446). 
One possibility why the excellence initiative has not succeeded in creating productivitypromoting universities is that it is not funded well enough to make much of a difference. Its current annual budget of 533 million Euro is split over more than 11 universities, constituting less than 1 percent of Germany's public university expenditure and a mere tenth of Harvard's budget alone. ${ }^{3}$ Therefore, identifying more productive universities, rather than actually generating a productivity-enhancing environment, may be all that one can demand from the excellence initiative.

\section{Third party funding}

Some claim that DFG funding is unrelated to productivity (Münch, 2006: p. 474). Others contradict that DFG funding is correlated to research excellence, while leaving unclear whether it helps those who have been more productive in the first place or indeed increases the productivity of researchers, irrespective of their prior achievements (Auspurg et al., 2008; Hornbostel, 2001: p. 536; Jansen et al., 2007).

We can give a clear answer to who is correct in this debate. Our data shows that when a researcher has been funded by the DFG twice as often, his or her publications increase 33 percent above what is typical for this researcher, holding all other influences constant (Model 4 of Table 3). ${ }^{4}$ Note that this is similar to other studies, which found that a doubling of DFG funding increases the productivity of business faculties by 24 percent (Albers, 2015: p. 25). But while these studies cannot tell which way the causality runs, we can show that productive researchers do not simply get more funding in the first place, but that the same researcher indeed publishes more after getting funded, irrespective of her or his prior productivity.

While this confirms fears that universities of excellence do not produce more productive researchers, it contradicts complaints that individual DFG funding is ineffective (cf. Münch, 2006: p. 477f.). However, note that this is only true for SSCI articles. We did not find that DFG funding gets the same researcher to publish more monographs or non-SSCI articles (nor is it related to publishing more monographs or non-SSCI articles when comparing researchers). Note also that while a typical male researcher publishes 43 percent more articles than he usually does after receiving DFG funding, a female researcher does not increase her publications significantly after receiving funding. This, as well as other results, support the theory of limited differences, to explain why women are less productive than men.

\section{Gender and children}

The theory of limited differences posits that at each level of experience, women are only marginally less productive than men, but suggests that these limited differences accumulate over time, as past productivity facilitates future productivity (Jonathan R. Cole \& Singer,

\footnotetext{
3 https://www.dfg.de/en/service/press/press_releases/2019/press_release_no_34/index.html https://www.destatis.de/DE/Presse/Pressemitteilungen/2020/04/PD20_143_213.html. Harvard University financial report fiscal year 2019, page 6. https://finance.harvard.edu/files/fad/files/fy19_financial_overview. pdf.

4 We only counted the number of grants; it would be fruitful for future research to examine the actual funding that was received per grant.
} 
1991: p. 282ff.). Our results are compatible with this theory, as we found that women are only 9 percent less productive than men at the same level of prior publication experience, but 26 percent less productive overall (Model 1 of Tables 1 and 2). This suggests that about two thirds of the female disadvantage stems from a process of cumulative disadvantage, while only about one third exists regardless of prior experience.

Xie and Shauman (1998: p. 864; also cf. Jadidi et al., 2018: pp. 150011-7) have argued that the female productivity puzzle is actually not a puzzle, as the lower female productivity can be explained through less access to career stages. At first sight, our results support their argument, insofar as accounting for career stages somewhat reduces the female productivity gap from 26 to 20 percent (Model 1 and 2 of Table 1). However, Models 1 and 2 of Table 2 show that what drives the influence of career stages is actually the publication experience that comes with career stages, rather than career stages per se. In other words, women do not publish less because they do not get to advanced career stages, but because they have less experience with publishing early in their career. While this reduces the female productivity disadvantage from 26 to about 9 percent, we cannot explain away the remaining effect through children, different from what others suggest (Mason et al., 2013: p. 29), but again similar to what the theory of limited differences postulates (Jonathan R. Cole \& Singer, 1991: p. 288). We suggest that existing research may have confused population-/ between-differences with intra-individual/ within-differences because we do find that mothers as a group are less productive, while we do not find that having children makes the same researcher less productive.

Different from what others have found, we can show that the circumstance that women publish less is hardly mitigated through dissimilar access to career stages, international experience, social capital, quality of one's university or third-party funding (Jadidi et al., 2018: pp. 1750011-19; Jaksztat, 2017: p. 357). Quite the opposite: while a man who gets third party funding exceeds his average publication trajectory very significantly, a woman who gets funded by the DFG is no more productive than she would have been in the absence of funding (Models 5 and 6 of Table 3). This is disconcerting for anyone who wants women to succeed in academia, because it seems that whatever increases productivity helps men more than women. The same is the case for career stages. If men make it to higher career stages, they turn these into publications more than women do. This would imply that helping women to reach higher career stages would not help them to be more productive, while men who get to higher career stages do increase their productivity more than women do. One exception is experience abroad, which consistently influences the productivity of women about twice as much as of men. This confirms Kathrin Zippel's (2017) argument that women, even more than men, may be able to make up for disadvantages at home by accumulating prestige or experience abroad. Giving women more opportunities to spend time abroad may therefore be a good way to help them to become similarly productive as men.

\section{Comparison to sociology}

Lutter and Schröder (2020; also cf. 2014, 2016) have conducted a similar study in German sociology. We are thus able to show which findings can be generalized to both disciplines. Most importantly, Lutter and Schröder also find that female sociologists publish 31 percent less before including controls (contrasting the effect size and constant of Model 1 of their Table 2). Again, while women are more negatively affected by childbirth than men, the effect of children hardly explains their generally lower productivity (Model 2), and neither 
do career stages (Model 3). However, female sociologists publish only 20 percent less after adjusting for prior publications together with other covariates (Model 4). Similar to political science, it therefore seems as if women mainly publish less because they have less experience with publishing early on, not because they have children. Similar to political science, Lutter and Schröder, (2020) also found that: 1) researchers become more productive after a $\mathrm{PhD}$ and then less productive after a professorship, 2) having published more SSCI articles in the past strongly predicts publishing more SSCI articles in the future when comparing researchers, but not within the career of each researcher, 3) DFG grants increase productivity, more for men than for women, though the effect is statistically insignificantly for both (Table 2 and 3). Lutter and Schröder also show that the productivity of women who were more successful in the first place suffer less from children than of women who were less successful in the first place (Fig. 1), which again suggests that fewer early successes, rather than childbirth, explain why women publish less in the long run. Thus, many of the effects that we show for political science are similarly found in sociology and therefore exist across disciplines.

\section{Policy implications}

Our results indicate that to make women succeed in academia, it is particularly important to get them to publish early on, as this publication experience, rather than e.g. access to formal career stages or DFG funding, explains later productivity and thus closes a large part of the female productivity gap. This puts those in a difficult position who want to support female academics, because it is easier to create preferential access of women to career stages or to DFG funding (both of which do not seem to have a large effect however), rather than making women publish more (which does have a strong effect, but which women have to do themselves). Overall, the results suggest that what stands most in the way of women succeeding in academia is their initially slightly lower productivity, which becomes larger and larger as early publication experience leads to later productivity. Thus, any program that boosts female productivity early on or gets women to have more international experience is probably more helpful in making female academics more productive than funding, preferential access to postdocs or to professorships.

Other policy implications are that there is clearly an effect of DFG funding on the production of SSCI articles. However, the German Research Council might want to consider whether it is a problem that researcher do not publish more monographs or non-SSCI articles after receiving DFG funding. Also, for those who have an interest in making the German excellence initiative a success, it is important to note that this is not yet the case in political science. Note that our results are exploratory in this regard however, as we do not know how much funding political science departments have received and because we had to count every university as a university of excellence which received this title at least once.

\section{Implications for the careers of individual researchers}

Our results can also guide researchers who aspire to be productive or wonder whether they will be. The results suggest that researchers who publish more than others early on can expect this to endure. If, however, one recognizes that others initially publish more than oneself, then this is unlikely to change and it is very unlikely that one will catch up, as 
productivity differences between researchers increase over time. It therefore seems important to publish a lot early on, to gauge one's potential, but also because early publications appear to lead to later publications, differentiating researchers that become more and more productive over time from researchers that fall further and further behind. Since this tends to disadvantage women, it is especially important for them to get a head start, to avoid falling into the trap of accumulative disadvantage. While this may sound fatalistic for latecareer researchers with few publications, the main takeaway for early-career researchers and especially women can be positive: if they manage to publish a lot early in their career, they can expect their success to continue. If young researchers find they lag behind their colleagues however, they should consider that the data suggests that this is unlikely to change.

While early publications seem a powerful predictor for later productivity, many other influences appear fairly unimportant. Notably, visiting universities of excellence seems a worthless effort, whose appeal may result from an ecological fallacy: Comparing publications may give the correct impression that researchers from universities of excellence are more productive than others. However, this is a selection, not a departmental effect, in that more productive researchers select into elite departments, yet these departments fail to make researchers more productive. Similarly, parents and especially mothers may seem like a less productive group, but the data suggests that individual researchers need not worry that having children will lower their productivity below what has been typical for themselves before they had children. Again, a different impression probably results from an ecological fallacy: confusing differences between groups versus differences within individual careers. One aspect that does have a strong influence is getting DFG funding, which indeed seems to increase future productivity, especially for men; while international experience seems to increase productivity especially for women.

Note however, that these results are for political science only. While they are strikingly similar to sociology, it stands to be seen if they are found in other disciplines as well. Note also that these results remain only correlational, so it would be interesting to see which of the effects hold when they are administered as an intervention.

Supplementary Information The online version contains supplementary material available at https://doi. org/10.1007/s11192-021-04175-8.

Funding Open Access funding enabled and organized by Projekt DEAL.

Open Access This article is licensed under a Creative Commons Attribution 4.0 International License, which permits use, sharing, adaptation, distribution and reproduction in any medium or format, as long as you give appropriate credit to the original author(s) and the source, provide a link to the Creative Commons licence, and indicate if changes were made. The images or other third party material in this article are included in the article's Creative Commons licence, unless indicated otherwise in a credit line to the material. If material is not included in the article's Creative Commons licence and your intended use is not permitted by statutory regulation or exceeds the permitted use, you will need to obtain permission directly from the copyright holder. To view a copy of this licence, visit http://creativecommons.org/licenses/by/4.0/.

\section{References}

Albers, S. (2015). What drives publication productivity in German business faculties? Schmalenbach Business Review, 67(1), 6-33. https://doi.org/10.1007/BF03396921

Allison, P. D., \& Stewart, J. A. (1974). Productivity differences among scientists: Evidence for accumulative advantage. American Sociological Review, 39(4), 596-606. https://doi.org/10.2307/2094424 
Auspurg, K., Hinz, T., \& Güdler, J. (2008). Herausbildung einer akademischen Elite? KZfSS Kölner Zeitschrift Für Soziologie Und Sozialpsychologie, 60(4), 653-685. https://doi.org/10.1007/ s11577-008-0032-7

Becker, G. (1993). Human capital: A theoretical and empirical analysis, with special reference to education (3ed). University of Chicago Press.

Bolli, T., \& Somogyi, F. (2011). Do competitively acquired funds induce universities to increase productivity? Research Policy, 40(1), 136-147. https://doi.org/10.1016/j.respol.2010.10.001

Bourdieu, P. (1986). The Forms of Capital. In J. G. Richardson (Ed.), Handbook of Theory and Research for the Sociology of Education (pp. 241-258).

Bourdieu, P. (2004). Science of science and reflexivity. University of Chicago Press.

Carayol, N., \& Matt, M. (2006). Individual and collective determinants of academic scientists' productivity. Information Economics and Policy, 18(1), 55-72. https://doi.org/10.1016/j.infoecopol.2005.09.002

Cole, J. R., \& Singer, B. (1991). A theory of limited differences: Explaining the productivity puzzle in science. In H. Zuckerman, J. R. Cole, \& J. T. Bruer (Eds.), The outer circle: Women in the scientific community (pp. 277-310). Norton.

Cole, J. R., \& Zuckerman, H. (1987). Marriage, motherhood and research performance in science. Scientific American, 256(2), 119-125.

Cole, S. (1979). Age and scientific performance. American Journal of Sociology, 84(4), 958-977. https://doi.org/10.1086/226868

DFG (2013). Excellence Initiative at a Glance. The Programme by the German Federal and State Governments to Promote Top-level Research at Universities. The Second Phase 2012 - 2017. Graduate Schools - Clusters of Excellence - Institutional Strategies. DFG.

Dubois, P., Rochet, J.-C., \& Schlenker, J.-M. (2014). Productivity and mobility in academic research: Evidence from mathematicians. Scientometrics, 98(3), 1669-1701. https://doi.org/10.1007/ s11192-013-1112-7

Fernández-Zubieta, A., Geuna, A., \& Lawson, C. (2015). Productivity pay-offs from academic mobility: Should i stay or should i go? Industrial and Corporate Change, 25(1), 91-114. https://doi.org/10. 1093/icc/dtv034

García-Suaza, A., Otero, J., \& Winkelmann, R. (2020). Predicting early career productivity of PhD Economists: Does advisor-match matter? Scientometrics, 122(1), 429-449. https://doi.org/10.1007/ s 11192-019-03277-8

Gerhards, J. (2002). Reputation in der deutschen Soziologie - zwei getrennte Welten. Soziologie, 31(2), 19-33.

Hix, S. (2004). A global ranking of political science departments. Political Studies Review, 2(3), 293313. https://doi.org/10.1111/j.1478-9299.2004.00011.x

Hornbostel, S. (2001). Third party funding of German Universities. An indicator of research activity? Scientometrics, 50(3), 523-537. https://doi.org/10.1023/A:1010566916697

Hunter, L. A., \& Leahey, E. (2010). Parenting and research productivity: New evidence and methods. Social Studies of Science, 40(3), 433-451. https://doi.org/10.1177/0306312709358472

Jadidi, M., Karimi, F., Lietz, H., \& Wagner, C. (2018). Gender disparities in science? Dropout, productivity, collaborations and success of male and female computer scientists. Advances in Complex Systems, 21(03n04), 1750011. https://doi.org/10.1142/s0219525917500114

Jaksztat, S. (2017). Geschlecht und wissenschaftliche Produktivität. Erklären Elternschaft und wissenschaftliches Sozialkapital Produktivitätsunterschiede während der Promotionsphase? Zeitschrift für Soziologie, 46(5), 347-361, doi:https://doi.org/10.1515/zfsoz-2017-1019.

Jansen, D., Wald, A., Franke, K., Schmoch, U., \& Schubert, T. (2007). Drittmittel als Performanzindikator der wissenschaftlichen Forschung. KZfSS Kölner Zeitschrift Für Soziologie Und Sozialpsychologie, 59(1), 125-149. https://doi.org/10.1007/s11577-007-0006-1

Joecks, J., Pull, K., \& Backes-Gellner, U. (2014). Childbearing and (Female) research productivity: A personnel economics perspective on the leaky pipeline. Journal of Business Economics, 84(4), $517-530$

Johnson, G. E., \& Stafford, F. P. (1974). The earnings and promotion of women faculty. The American Economic Review, 64(6), 888-903.

Jungbauer-Gans, M., \& Gross, C. (2013). Determinants of success in university careers: Findings from the German academic labor market. Zeitschrift Für Soziologie, 42(1), 74-92.

Kyvik, S. (1990). Motherhood and scientific productivity. Social Studies of Science, 20(1), 149-160. https://doi.org/10.1177/030631290020001005

Kyvik, S., \& Teigen, M. (1996). Child care, research collaboration, and gender differences in scientific productivity. Science, Technology \& Human Values, 21(1), 54-71. https://doi.org/10.1177/01622 4399602100103 
Leahey, E. (2006). Gender differences in productivity: research specialization as a missing link. Gender \& Society, 20(6), 754-780. https://doi.org/10.1177/0891243206293030

Lee, D. H. (2019). Predicting the research performance of early career scientists. Scientometrics, 121(3), 1481-1504. https://doi.org/10.1007/s11192-019-03232-7

Lindahl, J., Colliander, C., \& Danell, R. (2020). Early career performance and its correlation with gender and publication output during doctoral education. Scientometrics, 122(1), 309-330. https://doi. org/10.1007/s11192-019-03262-1

Long, J. S. (1978). Productivity and academic position in the scientific career. American Sociological Review, 43(6), 889-908.

Long, J. S. (1990). The origins of sex differences in science. Social Forces, 68(4), 1297-1316.

Long, J. S., Allison, P. D., \& McGinnis, R. (1993). Rank advancement in academic careers: Sex differences and the effects of productivity. American Sociological Review, 58, 703-722.

Lutter, M., \& Schröder, M. (2014). Who Becomes a Tenured Professor, and Why? Panel Data Evidence from German Sociology, 1980-2013. MPIfG Discussion Paper. Cologne: Max Planck Institute for the Study of Societies.

Lutter, M., \& Schröder, M. (2016). Who becomes a tenured professor, and why? Panel data evidence from German sociology, 1980-2013. Research Policy, 45(5), 999-1013. https://doi.org/10.1016/j.respol. 2016.01.019

Lutter, M., \& Schröder, M. (2020). Is there a motherhood penalty in academia? The gendered effect of children on academic publications in German sociology. European Sociological Review, 36(3), 442-459. https://doi.org/10.1093/esr/jcz063

Marginson, S. (2019). Limitations of human capital theory. Studies in Higher Education, 44(2), $287-301$. https://doi.org/10.1080/03075079.2017.1359823

Mason, M. A., Wolfinger, N. H., \& Goulden, M. (2013). Do babies matter? Gender and family in the ivory tower. Rutgers University Press.

Merton, R. K. (1968). The Matthew effect in science. Science, 159(3810), 56-63. https://doi.org/10.1126/ science.159.3810.56

Merton, R. K. (1973). The normative structure of science. In N. W. Storer (Ed.), The sociology of science (pp. 267-278). University of Chicago Press.

Möller, T., Schmidt, M., \& Hornbostel, S. (2016). Assessing the effects of the German excellence initiative with bibliometric methods. Scientometrics, 109(3), 2217-2239. https://doi.org/10.1007/ s11192-016-2090-3

Münch, R. (2006). Wissenschaft im Schatten von Kartell, Monopol und Oligarchie. Die Latenten Effekte Der Exzellenzinitiative. Leviathan, 34(4), 466-486. https://doi.org/10.1007/s11578-006-0065-0

Rivera, L. A. (2017). When two bodies are (not) a problem: Gender and relationship status discrimination in academic hiring. American Sociological Review, 82(6), 1111-1138. https://doi.org/10.1177/00031 22417739294

Sax, L., Hagedorn, L., Arredondo, M., \& Dicrisi, F. (2002). Faculty research productivity: exploring the role of gender and family-related factors. Research in Higher Education, 43(4), 423-446. https://doi. org/10.1023/A:1015575616285

Schröder, M., Lutter, M., \& Habicht, I. M. (2021). Publishing, signaling, social capital, and gender: Determinants of becoming a tenured professor in German political science. PloS one, 16(1), e0243514.

Strober, M. H., \& Quester, A. O. (1977). The earnings and promotion of women faculty: Comment. The American Economic Review, 67(2), 207-213.

Xie, Y., \& Shauman, K. A. (1998). Sex differences in research productivity: New evidence about an old puzzle. American Sociological Review, 63(6), 847-870. https://doi.org/10.2307/2657505

Zippel, K. (2017). Women in global science. Advancing academic careers through international collaboration. Stanford University Press. 